\title{
Spatial Analysis of International Tourist Movement to Langkawi for 2010 and 2011
}

\author{
Nur Fatma Zuhra Basiron ${ }^{1}$, Azizul Ahmad ${ }^{2}$, Tarmiji Masron ${ }^{3}$ \\ ${ }_{1,2,3}$ Geography Section, School of Humanities, 11800 Penang, Malaysia
}

\begin{abstract}
Tourism is a temporary movement of people to a destination of their choice intended for leisure or recreation. The resulting of this movement can be divided into interdestination dan intradestinastion. This study is about interdestination movement which is characterised by movement from tourist-generating regions to one or more destinations. This research aims to analyse the movement of international tourist who come to Langkawi in 2010 and 2011. The application geographic information system (GIS) is aids in visualizing spatial data through mapping. Regression analysis using SPSS was also used to examine the relationship between the distance and the amount of flow that exists. Map of the distribution and flow of tourist was produced to facilitate the analysis. The results of the analyses show that the tourist movement is driven by certain factors such as climatic, economic, distance and etc. Regression analysis showed the nexus between the distance and the amount of the tourist flow was not strong. Map produced can be used by LADA specifically for planning marketing strategies and etc.
\end{abstract}

\section{Introduction}

Tourism is one of the highest industry to generate income on the twenty-first century and the number of international tourist arrivals have increased significantly [1] to Malaysia. Tourism is the largest contributor to the economy in developing countries, including Malaysia when the total expenditure in 2000 was increased to RM58,347 to RM18,756 in 2010 [2]. Currently, tourism in Malaysia is a significant achievement. This is because Malaysia is blessed with a beautiful environment plays an important role in world of tourism. Tourism is the temporary movement of people to destination outside the home and workplace to do the activities and the use of the facilities available at the destination visited to meet their needs and desires [3]. Tourism can be regarded as a phenomenon arising from the travel and temporary accommodation primarily for leisure or recreational purposes [4]. First is the purpose of travel must be met, such as for vacation travel, visiting relatives, and include the Pilgrimage, sports, health and education. For the trip, the tour usually do not qualify as migration, military activities, commitment to work and refugees [5]. Geographic Information System (GIS) is a computer-aided tool to input, manage, display and analyses spatial data. GIS technology is a technology developed and are now applied in various fields, including tourism. In planning and tourism development, decision making becomes very complex in which organizations and communities need to take into account the economic, social and environment for sustainable tourism development [6]. 


\section{Tourist Movement Concept}

Tourism interdestination movement pattern is a spatial phenomenon involving the movement of people between the two areas [7]. Movement of tourists can be presented in the form of maps at different scales to represent points and lines that emphasize the space relationship between two or more locations [8]. Tourist movement is divided into two on different scales of interdestination the movement of tourists at the macro and micro level intradestination. At macro level, the tourists move from their area of residence (origin) to a destination of choice [9]. Furthermore, for intradestination limited movement in only local destinations that tourists travel from one site to the other tourist spots in the same destination [8].

Flogenfeldt, (1999) in his study, the identified four types of patterns taken by tourists Norway: day trips, visits the resort, based holiday and the round trip [10]. Lew \& Mckercher (2002) contributes to the literature by examining the relative location of the destination in the itinerary of a larger pattern through alternative approaches and destinations are classified into five types: Single Destination, Gateway Destination, Egress Destination, Touring Destination and Destination Hub [11]. Based on the study Lau \& Mckercher (2007) summarized the movement patterns into six categories: single point, base site, stopover, chaining loop, loop destination region, and complex neighbourhood. All the patterns on the characteristics of various travelers move from origin to destination and the destination [12].

\section{Methodology}

According to Ruslan Rainis \& Noresah (1998), the data in geographic information system database must be updated, clean and accurate [13]. In the context of this study, existing data are used. Data on international tourist arrivals by country of origin, who arrived in Langkawi in 2010 and 2011 obtained from the Langkawi Development Authority (LADA). Data obtained in the form of Microsoft Office Excel for the whole country in the world. Generally there are five stages in the implementation of the study. The first stage is a preliminary study and review of literature. The second stage is the collection of data and information, the third and final stage of data analysis is the conclusion. The process begins with a preliminary study with the understanding of the problem and review of literature. At this stage involves the process of identifying problems and research questions. This stage involves the formation of the objectives, the scope of the study and the conceptual framework. Formulation of objectives and scope of the study and a conceptual framework to help researchers study the effectiveness of the process because the target has been set. The next stage is to gather data and information. The data used is the existing data obtained from the LADA.

ArcGIS software is used to produce maps flow of international tourists who come to Langkawi and map the distribution of tourists. SPSS was used to perform logistic regression analysis to examine the relationship between the distance and the amount of flow that exists. The final stage is concluded. The analysis concluded and recommendations made in the future. Finally, the writing of the report. Spider diagram method can also be placed weights (line of each travellers is based on the colour or thickness depending on the variables set by the researchers) or do not put the weight (in which every tourist is calculated the same) [14]. This method produces a direction coming attractions. By using this method, the flow of tourists who come to Langkawi can easily and clearly. This method can also be applied in business activity in the identification of customers and the number of patients coming to the hospital. In this study, annual data 2010 and 2011 international tourists who come to Langkawi used. 


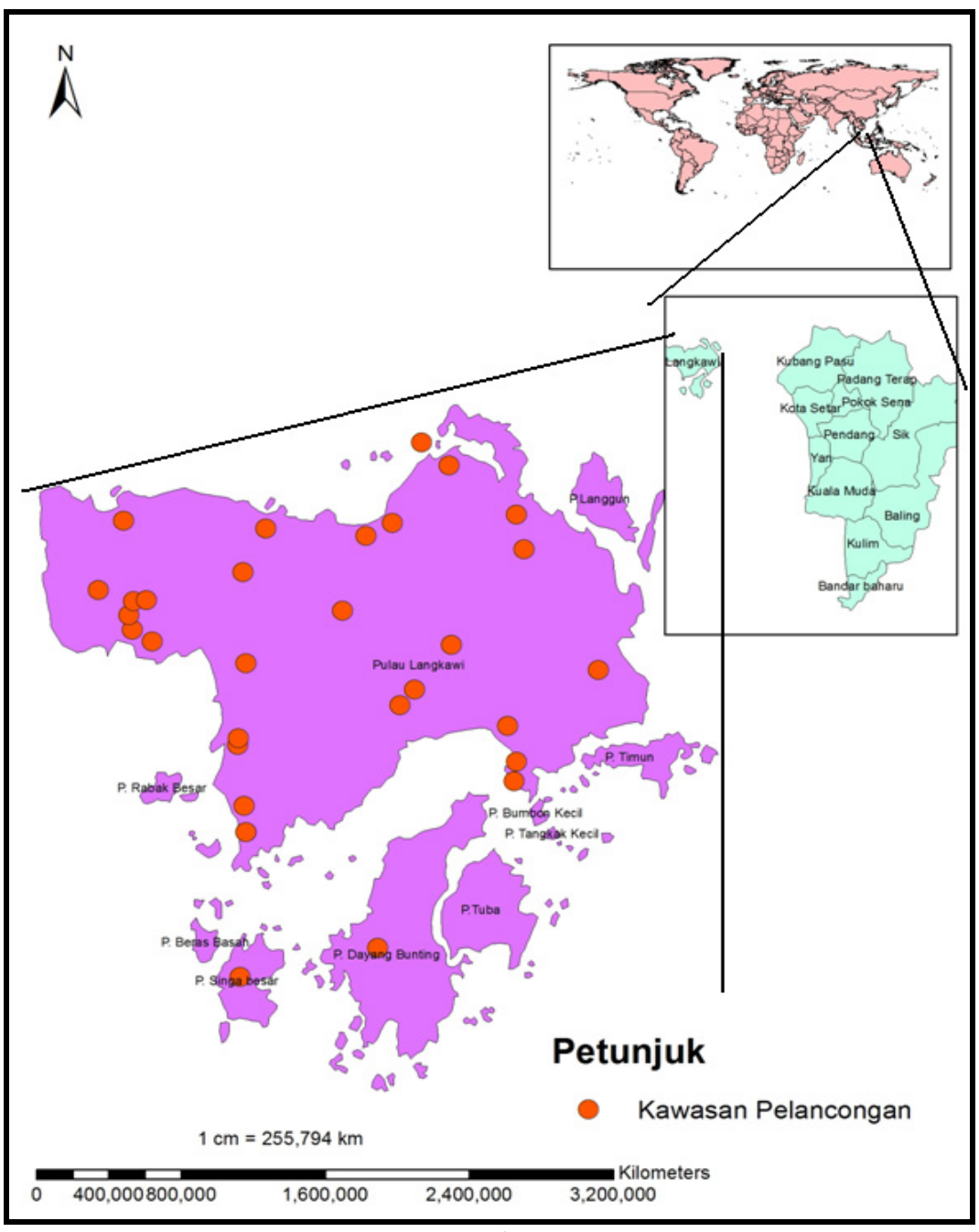

Figure 1. Study Area Map

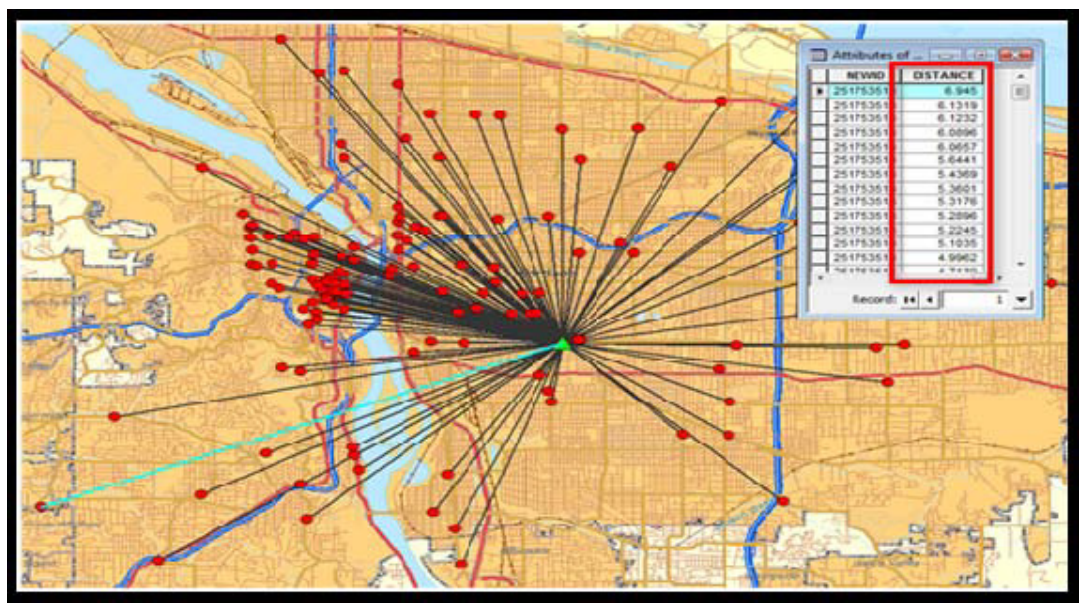

Figure 2. Example of Analysis Using Spider Diagrams

(Source: ESRI, 2013)4 Discussion: International Tourist Flow Movement 
Flow system in human and physical geography is the focus of the investigation because it involves movement across the space between their origin and destination to reallocate water, sediment, energy, population, product and economic activity [15]. In the context of tourism, tourist flow movement is the interaction between origin and destination were not randomly happen because according to certain regulations and is influenced by various factors push and pull factors [16]. In the year 2010, a total of 49 flow movement of tourists from overseas countries exist in Langkawi.

To see more of the existing flow, the flow map has been produced (Figure 4:1). The highest number of visitors recorded was from the United Kingdom about 103,275 tourists and travellers the least visited Langkawi in the same year are tourists from Laos which consist of 115 people. Overall, the number of international tourists to Langkawi in 2010 amounted to 969,505 people.

Movement flow of international tourists to Langkawi in 2011, however, there is a flow of movement similar to the trends that existed in 2010 and the number of countries involved are still the same, not increase or decrease the total of 49 countries. However, the number of international tourists to Langkawi showed that in 2010 the total of international tourists is about 969,505 people and 980,622 people in 2011. It occurs increase about 11,117 people.

The highest international tourists in 2011 were tourists who came from Saudi Arabia which is about 91,586 people and is followed by tourists from the United Kingdom which is about 84,664 people, 78,262 people of Australia, China 72,776 and India 65,906 people. Based on the maps that have been produced (Figure 4.2) clearly shows that most of the tourist flow that exists in Langkawi is largely concentrated in Europe. This clearly shows that among the factors that affect the existence of such a flow is caused by climatic factors and economic factors.

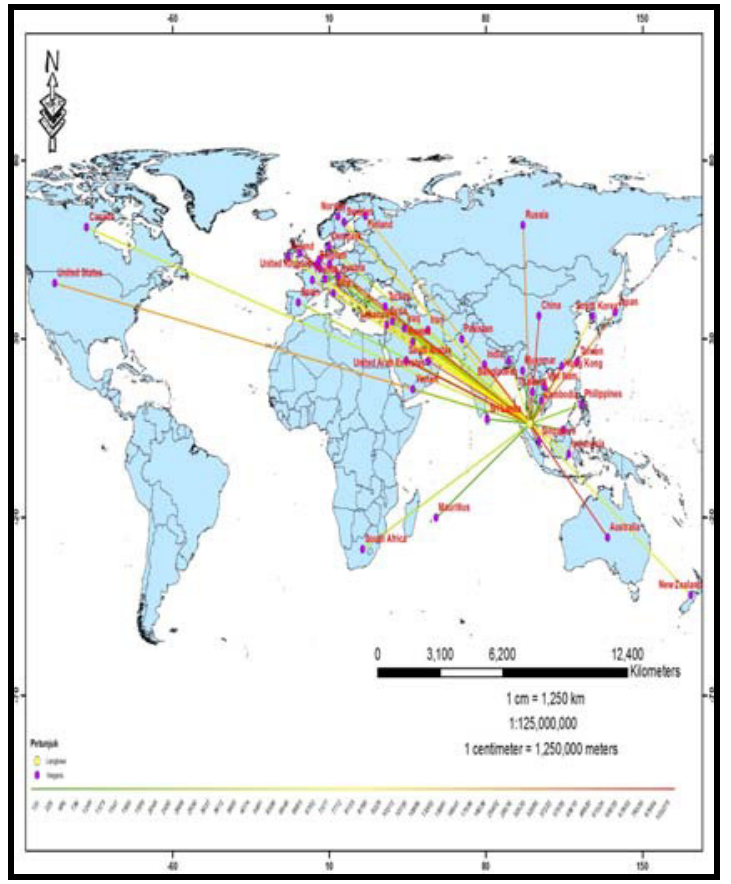

Figure 3. Flow Map International Tourist Movements to Langkawi in 2010

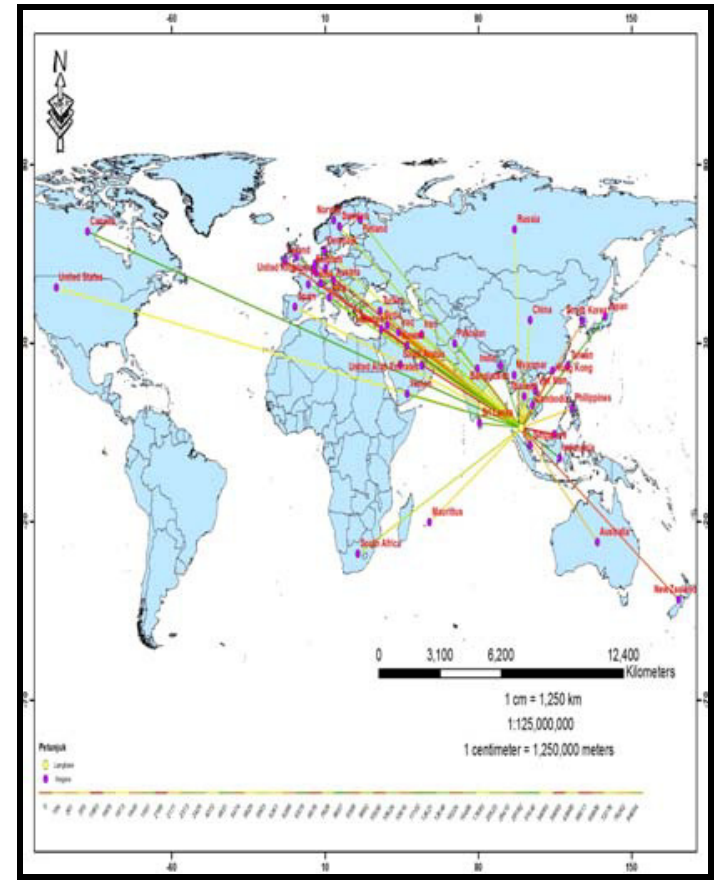

Figure 4. Flow Map International Tourist Movements to Langkawi in 2011 
Before logistic regression analysis was carried out using SPSS, distance and total flow for each countries 'log' right to use the measurement at accessibility. Each number is the 'log' right is to linearize the non-linear lines and to reduce all values for all of these values are too large.

$\mathrm{Ho}=$ The dependent variable is the number of tourists has no relevance to the independent variables of distance.

$\mathrm{H} 1$ = The dependent variable is the number of tourists having a relationship with independent variables of distance.

Before the regression analysis conducted, a scatterplot showed to made for relationships between variables and the total distance travellers. The first result of table is not important because only lists a single variable we use as predictors. Among the important table is the model summary table (Table 4.2). This table provides the results $\mathrm{R}$ and $\mathrm{R} 2$. $\mathrm{R}$ value is 0.152 , which represents the simple correlation. $\mathrm{R}^{2}$ value indicates how much the dependent variable, "the tourists", can be explained by the independent variables, "distance". In this case, only $23.0 \%$ can be explained. Regression analysis using the SPSS output showed some results in the form of old fashion. The table first result is not important because only lists a single variable we use as predictors. Among the important table is the model summary table (Table 4.2). This table provides the $\mathrm{R}$ and $\mathrm{R} 2$. $\mathrm{R}$ value is 0.152 , which represents the simple correlation. $\mathrm{R}^{2}$ value indicates how much the dependent variable, "the number of tourists", can be explained by the independent variables, "distance". In this case, only $23.0 \%$ can be explained.

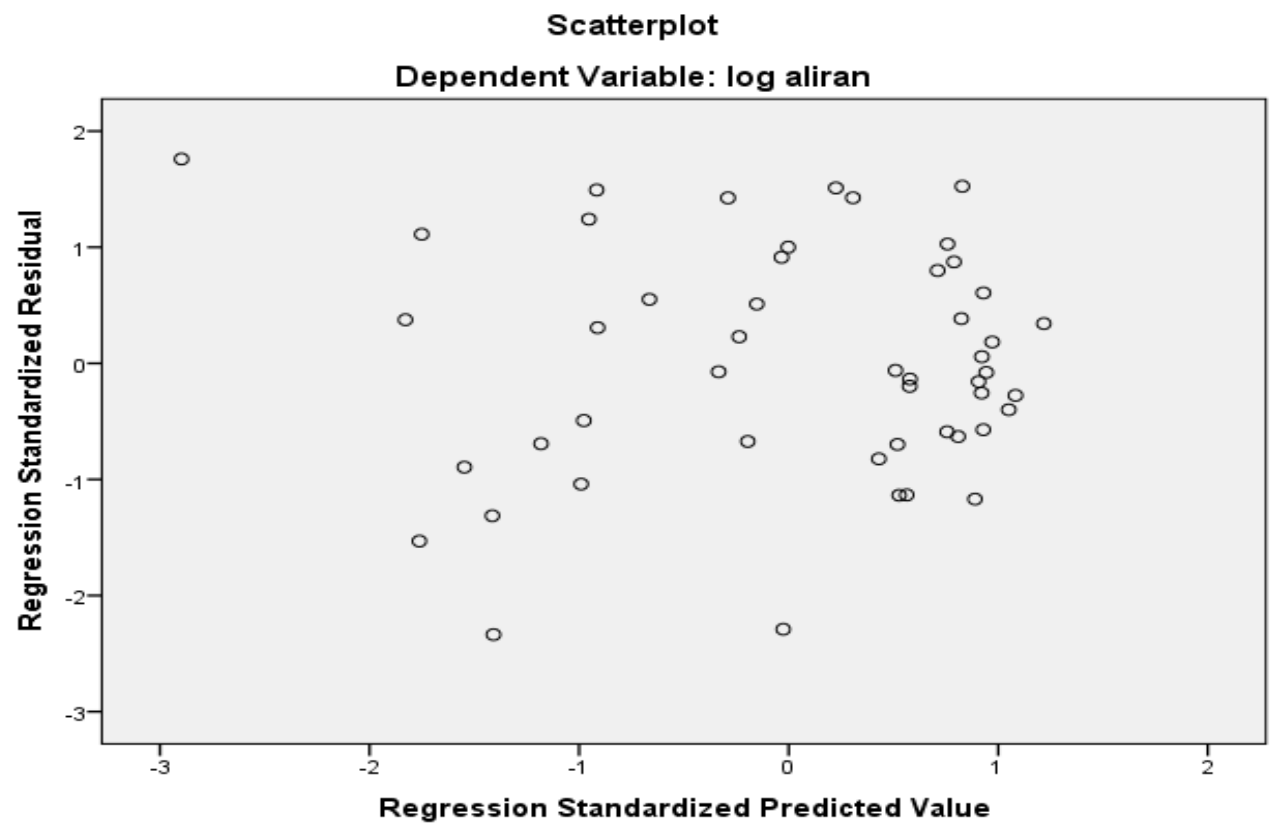

Figure 5. Scatterplot

Model Summary ${ }^{b}$

Table 1. Model Summary

\begin{tabular}{|c|c|c|c|c|}
\hline Model & $\mathrm{R}$ & $\mathrm{R}$ Square & Adjusted R Square & $\begin{array}{c}\text { Std. Error of the } \\
\text { Estimate }\end{array}$ \\
\hline 1 & $.152^{\mathrm{a}}$ & .023 & .002 & .674652601841138 \\
\hline
\end{tabular}

a. Predictors: (Constant), distance log

b. Dependent Variable: flow log 
The next table is the ANOVA table. This table shows that the regression model predicts significant outcome variable. If the p-value less than 0.05 indicates that overall, the model shows the significant variables can predict the outcome. In this case the model doesn't show the significant

Table 2. ANOVA

$\operatorname{ANOVA}^{\mathrm{a}}$

\begin{tabular}{|ll|l|l|l|l|l|}
\hline Model & & Sum of Squares & df & Mean Square & F & Sig. \\
\hline \multirow{4}{*}{1} & Regression & .508 & 1 & .508 & 1.117 & $.296^{\mathrm{b}}$ \\
& Residual & 21.392 & 47 & .455 & & \\
& Total & 21.901 & 48 & & & \\
\hline
\end{tabular}

a. Dependent Variable: flow log

b. Predictors: (Constant), distance log

Table 4.4 shows the Coefficients which provides information on each predictor variable. In this case shows that the p-value for the distance showed no significant value and the p-value for the constant is not significant. Therefore Ho accepted the dependent variable, the number of tourists has no relevance to the independent variables of distance. The conclusions show that the low value of $\mathrm{R}^{2}$ shows the relationship between distance and the number of tourists is weak and shows the distance variable is not significant. The greater the number of potential destinations within a certain time or distance range, the greater accessibility and more convenient destination is within the maximum range, the higher the level of accessibility [17]. This indicates that the element at tourist destination, even if they had to go through a long distance. However, in some cases, most of the movement of international tourists in occur between adjacent countries [18]. The Increase of distance that must be taken by tourists may lead to increased costs, especially transport, accommodation costs, expenses costs and other. In addition, the distance requires travellers to take a long time before reaching a tourism destination of choice. Therefore tourism would choose to travel to a country that is closer and has a charm that is approximately equal to the destination [18]. Distance and cost is a factor that is often considered by travellers. Tourists will usually try to avoid traveling to countries where consumer prices is higher than in the home economy, while tourists will get better value for money if they travel to countries where consumer prices are lower from home [19]. In this case study, the arrival of tourists from Europe are more. This is because the value of the Malaysian currency is lower than the value of the currency part of those encouraging them to come even if the distance between Malaysia and Europe is far away. Therefore, travellers can fly direct to Langkawi. Langkawi also provide facilities for international travellers coming through waterways using their personal ship.

Table 3. Coefficients Model

Coefficients $^{\mathrm{a}}$

\begin{tabular}{|c|c|c|c|c|c|c|c|}
\hline \multirow[t]{2}{*}{ Model } & \multicolumn{2}{|c|}{$\begin{array}{l}\text { Unstandardized } \\
\text { Coefficients }\end{array}$} & $\begin{array}{l}\text { Standardized } \\
\text { Coefficients }\end{array}$ & \multirow[t]{2}{*}{$\mathrm{t}$} & \multirow[t]{2}{*}{ Sig. } & \multicolumn{2}{|c|}{$\begin{array}{l}\text { 95.0\% Confidence Interval for } \\
\text { B }\end{array}$} \\
\hline & $\mathrm{B}$ & Std. Error & Beta & & & Lower Bound & Upper Bound \\
\hline $\begin{array}{l}\text { Constan } \\
\mathrm{t}\end{array}$ & 2.673 & & & & .026 & .328 & \\
\hline $\begin{array}{l}\text { Log } \\
\text { distance }\end{array}$ & .325 & .307 & .152 & 1.057 & .296 & -.293 & .943 \\
\hline
\end{tabular}

a. Dependent Variable: flow log

\section{Findings}

The conclusion that can be drawn is that all objectives of the study have been answered in this analysis. Moreover, the use of GIS to mapping the spatial data to produce flow maps have been made. 
The map produced was used for the process of analysing the movement of tourists. The analysis of the main factors that influence is the climate and economy. However, these factors do not affect some of the country's total tourism is high throughout the year. The maps produced to facilitate the process for analysing the movement of tourists. The regression analysis indicated that the relationship between distance and the number of tourist arrivals is not strong. This is because the number of tourist arrivals is not only influenced by the distance but also other factors.

\section{Conclusion and Future Recommendations}

Although the study was able to achieve all the objectives that have been set, but there are some suggestions that should be expanded as well as improve on the next study. The weakness of this study is the researchers looked at the factors that influence the global tourists. Thus, for future studies are expected to see the real factors that influence tourists. Moreover, in a future study, researchers can include more variables such as the total population of the country of origin, economic status, educational level and other in the regression analysis to find out the relationship of these factors with the number of flows that exist. Furthermore, studies in the future are expected to try to incorporate movement in tourist's interdestinations and intradestinations. In conclusion, the study has achieved the objectives set out by analysing the flow of tourists to Langkawi movement using GIS as a tool to visualize data through the mapping space. The study also successfully produced logistic regression analysis showed the distance and number of flows that exist do not have a strong relationship [20].

\section{Acknowledgement}

"The authors would like to extend their appreciation to the Universiti Sains Malaysia for the Research University Grant entitled 'Tourism Decision Support System' [Grant No. 1001/PTS/8660014] that makes this study and paper possible."

\section{References}

1. Rosilawati Zainol, Zainab Abu Bakar, Sayed Jamaluddin Sayed Ali. GIS application in identifying tourism resources in Southeast Asian.

2. Jabatan Perangkaan Malaysia. [Diakses pada 18 Oktober 2013]. Obtainedi from laman web http://www.statistics.gov.my/main/main.php. (2013)

3. Mathieson, A. \& Wall, G. Tourism: Economic, Physical and Social Impacts. Singapore: Longman Singapore Publishers (Pte) Ltd (1982)

4. D.G Pearce, Tourism Today: A Geographical Analysis 2nd Edn. New York: Longman Scientific \& Technical (1987)

5. D.B Weaver, Ecotourism. Australia: John Wiley \& Sons Australia, Ltd (2001)

6. T. Bahaire \& M. Elliott-White, The application of geographical informatics systems (GIS) in sustainable tourism planning: A review. Journal of Sustainable Tourism, 7, 2, 159-174 (1999)

7. S.L. Smith, Tourism Analysis: A Handbook. New York: Wiley (1990)

8. G.W. Lau, Mapping Tourist Movement Patterns: A GIS Approach. A thesis submitted in partial fulfilment of the requirements for the Degree Of Master Of Philosophy, The Hong Kong Polytechnic University, School Of Hotel And Tourism Management. Obtained September 4, 2013, from http://repository.lib.polyu.edu.hk/jspui/bitstream/10397/2261/2/b21459319.pdf (2007)

9. N. Leiper. The framework of tourism: Towards a definition of tourism, tourist, and the tourist industry. Annals of Tourism Research, 6, 4, 390-407 (1979)

10. T. Flogenfeldt, Traveler Geographic Origin and Market Segmentation: the Multi Trips Destination Case. Journal of Travel and Tourism Marketing, 8, 111-118 (1999)

11. A. Lew, B. Mckercher, Trip Destinations, Gateways and Itineraries: The example of Hong Kong. Tourism Management, 23, 609-621 (2002) 
12. G. Lau, B. Mckercher. Understanding Tourist Movement Patterns in a Destination: A GIS approach. Tourism and Hospitality Research , 7, 1, 39-49 (2007)

13. Ruslan Rainis \& Noresah Mohd Shariff. Sistem Maklumat Geografi. Kuala Lumpur: Dewan Bahasa dan Pustaka (1998)

14. ESRI. (2013). ArcGIS Resources. Obtained Januari 3, 2014, from ArcGIS Help 10.1: Create spider diagram (desire lines): http://resources.arcgis.com/en/help/main/10.1/index.html\#//000z00000043000000

15. Alber, R. F., Marcus, M. G., \& Olson, J. M. Geography's Inner World: Pervasive Themes in Contemporary American Geography. New Jersey: Rutgers University Press (1995)

16. B.G. Boniface \& C. Cooper, The geography of travel and tourism. Oxford: ButterworthHeinemann Ltd (1987)

17. R.L. Church \& J.R Marston, Measuring Accessibility for People with a Disability. Geographical Analysis, 35, 1, 83-96 (2003)

18. R. Burton. Travel geography, (2 ${ }^{\text {nd }}$ Ed.). London: Pitman Publishing (1995)

19. D.B. Weaber, M. Opperman, Tourism management. Australia: John Wiley \& Sons Australia, Ltd (2000)

20. Nur Fatma Zuhra Basiron. Analisis Ruangan Pergerakan Pelancong Antarabangsa Ke Langkawi Tahun 2010 Dan 2011. Universiti Sains Malaysia, Bahagian Geografi, Pusat Pengajian Ilmu Kemanusiaan. Minden, Pulau Pinang: Disertasi Sarjana Sains (Sains Maklumat Geografi) (tidak diterbitkan) (2014) 